\title{
Values Education: A Panacea for Social Reforms in Nigeria
}

\author{
Theresa Ebiere Dorgu $^{1}$, Nemine Ebi-bulami Bridget ${ }^{2}$, Olu-Obafemi Ebidewari Catherine ${ }^{3}$ \\ ${ }^{1}$ Department of Arts Education, Niger Delta University, Yenagoa, Nigeria \\ ${ }^{2}$ Department of Social Science Education, Niger Delta University, Yenagoa, Nigeria \\ ${ }^{3}$ Business Education Department, Adeniran Ogunsanya College of Education, Lagos, Nigeria
}

Email address:

ebiered@yahoo.com (Theresa E. D.), bridget.ebi1@gmail.com (N. Ebi-bulami B.), ebioludorgu@gmail.com (Olu-Obafemi E. C)

\section{To cite this article:}

Theresa Ebiere Dorgu, Nemine Ebi-bulami Bridget, Olu-Obafemi Ebidewari Catherine. Values Education: A Panacea for Social Reforms in Nigeria. Teacher Education and Curriculum Studies. Vol. 4, No. 1, 2019, pp. 27-32. doi: 10.11648/j.tecs.20190401.14

Received: January 31, 2019; Accepted: April 1, 2019; Published: May 15, 2019

\begin{abstract}
This paper attempted to establish values education as a panacea for social reforms in Nigeria. It held that values are principles that act as guidelines of our lives and that education serves as a major instrument for social reforms and together, "values education" plays a major role in the nation's bid to attain social reforms. It further listed some social issues and problems that have bedevilled the society, and the need to teach values education as a means for social reform listing its benefits, and that values education enlightens the youths, opens them to the world of opportunities to modify their disposition to life, and enables them to choose the right values based on sound reasoning where individuals and groups will shun violence and embrace togetherness and peaceful co-existence that values education ascribes to its beneficiaries. The author maintained that in the bid to achieve reforms in Nigeria, the knowledge of values education is a key instrument for such reforms, as this will inculcate in the citizenry, truth, moral values and ethics, justice and fair-play, honesty, patience, selflessness, integrity, etc. for the development of a better nation where citizens will live by morality and ethics developed in schools with a solid foundation built by families. The paper thus recommended among other things the need to sensitise the public on the usefulness of values education.
\end{abstract}

Keywords: Values Education, Reforms, Youths

\section{Introduction}

One of the most topical issues in the media in Nigeria today is social issues and problems. Though social issues and problems are global phenomena, but are considered rampant in Nigeria. The damages the nation has experienced due to social issues are numerous. Issues like corruption, unemployment, poverty, kidnapping, cultism, police extortion, bureaucracy in offices, election irregularities, drug abuse, prostitution, abuse of power by government officials, examination malpractice, etc., the list is endless. All these have directly or indirectly affected the development of Nigeria as a nation and this calls for an urgent need for social reform in the nation. This reform sought can be obtainable through the teaching of values education to the youths. This will go a long way to reduce to a great extent the nuisance of social issues in our society. Values cannot be taught in isolation. It can be merged with the education of an individual. Values are principles that act as guidelines of our lives. Education serves as a major instrument for social reforms and values education plays a major role in the nation's bid to attain social reforms.

Ololube [1] noted that social reforms is a process whereby the values, attitudes or institutions of society like education, family and religion are modified and includes both natural processes and action programmes initiated by members of the affected community. This paper maintains that in the bid to achieve reforms in Nigeria, the knowledge of values education is a key instrument for such reforms, as this will inculcate in the citizenry, truth, moral values and ethics, justice and fair-play, honesty, patience, selflessness, integrity, etc. for the development of a better nation where citizens will live by morality and ethics developed in schools with a solid foundation built by families.

\section{The Concept of Values}

Generally, values are known to be the foundations for 
one's character as they guide behaviours and affect decisions. Values are standards, criteria for rules that give direction and determine how humans act, what is consider best and select from available choices. Values show the inner self and portray who a person is. Values define what is important, worthwhile and worth striving for. They determine what is considered right, wrong, good and bad. Values define the ideal principle. Values account for the stability of the social order as they provide the general guidelines for conduct in a given society. Values are the criteria people use in assessing their daily lives, arranging their priorities, measuring their pains and choosing between different courses of action.

\subsection{Positional Conceptualisation of Values}

Mondal [2] conceptualised that values are the basis for judgements about what is desirable, beautiful, proper, correct, important, worthwhile and good as well as what is undesirable, ugly, incorrect, improper and bad. Values provide general guidelines for behaviour, they are translated into more specific directives in terms of roles and norms. Values are internalised and transmitted from one generation to the next. Wikipedia [3] noted that values are the degree of importance of something or action, with the aim of determining what actions are best to do or what way is best to live. As such, values represent a wide range of ideas about the ends that men and women should pursue in their lives. Thus, the values of a society provide goals or ends for its members to aim for. Therefore, once values are learnt, values must be maintained and those who deviate from society's values must be brought back into line. Values define what is important, worthwhile and worth striving for. Dorgu and OluObafemi [4] opined that values occupy a central position in all human pursuits; explaining that types of values abound ranging from moral values, cultural values, humanistic values to economic, social, political and aesthetic values. And that values form a basis for social interaction in every society.

Bodunrin [5] is of the view that values are principles that determine one as an individual. From the above definitions, it is obvious that a value in its simplicity is seen as a measure of goodness or desirability. Values provide the general guidelines accepted for the behaviour of the people. Therefore, values like respect for human dignity, fundamental rights, private property, patriotism, helpfulness, honesty, good moral standards, etc. guide human behaviour in various ways. Values serve as an essential component in holding the society together and for making decisions at individual or national basis. This can only be possible when the right values are in place [4].

\subsection{Types of Values}

Values provide a general guideline for good conduct in the society. Thus, values serve as a guide to an individual's behaviour or attitude to others. Bergmark and Alerby [6] categorised values into six groups namely:

1. Moral values: These according to them are passed from one generation to the next by tradition. Moral values keep a person on the right path than the legal enforcement. They refer to attitudes and behaviours that a society considers necessary for co-existence, order and general wellbeing. Examples include respect for others, courage, self-control, honesty, kindness, integrity, etc.

2. Family values: These specifically exist where there is love between family members. Family values bind members of a family together than individual values. Such values are values that are meant to protect family names e.g. integrity.

3. Spiritual values: These are mostly attributed to God and are seen as divine. These are universal values because they cut across religions, cultural and racial differences and historical origins e.g. love, justice, truth, compassion, etc.

4. Individual values: These are values that are beneficial to individuals and they are seen as the most paramount.

5. Professional values: These values are such that will bind, protect and preserve various professional pride and integrity in order to keep members of such organisations motivated, protected and united.

6. National values: National values seek to provide equality and justice to all its citizens. Any violation of national values is punishable by the law of the nation.

Finally, there are general values such as democracy, freedom, right to dissent. These values are abstract in nature and pervade many aspects of life. The specific values are often stated in specific terms e.g. one may value physical health over affluence, or silk over nylon. Values generally range from highly abstract to specific levels.

\section{The Concept of Values Education and the Need for Values Education}

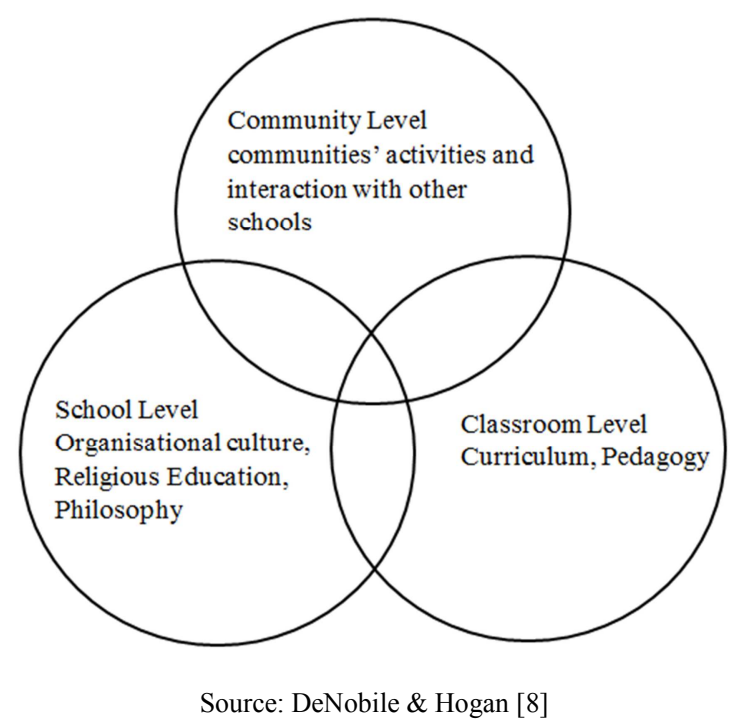

Figure 1. The three levels of Values Education.

Values Education simply put is a means of transmitting good values to individuals to enable them think and make 
better choices in life. Dike [7] noted that values education is educating for character and for good moral values. DeNobile and Hogan [8] categorised the need for values education into three (3) major areas that interact with each other, namely: Values education at the community level, the school level and the classroom level. This is shown in Figure 1.

\subsection{Values Education Levels}

Three levels of values education interaction can be glimpsed from the figure above. These three levels interact with one another thus:

a At the Community level: Values education comes into play as a means of interaction with the wider communities, and interaction with other schools. This provides experiences based on their knowledge from values education, such as respect, understanding, talks on moral dilemmas, and the state of their various communities. These help them to work on common goals, and improve their community life and standard.

b At the School level: Here direct teaching is considered like in the teaching of history, social studies, geography, culture and philosophy, and some religious background teachings that influence curriculum, moral values and pedagogy. This is done with the sole aim of changing the way the people reason, act with each other and live peacefully in the world, thereby creating people who are mindful of the needs of others in the same society.

c At the Classroom level: At this stage, students are taught directly the need to appreciate good values. This is exemplified in their being engaged in various activities which are designed to make them know and appreciate various values and how to apply such rules and codes of ethics in their daily living in and out of school and the society at large.

Robb [9] conceptualised values education as a process of teaching and learning about the ideals that a society deems important. Values education is simply a matter of developing appropriate behaviour and habits involving inculcation of certain virtues and habits [10].

The foregoing reveals that values education teaches positive behaviours and attitudes to imbibe for better living in society. It is the ability to make moral judgements based on sound reasoning, etiquette and an appropriate social behaviour. It further helps an individual to choose between competing values, thereby exercising their rights for moral judgement. Education transforms and changes the totality of an individual as to enable him or her fit into the society and develop the cultures and values of that society.

\subsection{The Need for Values Education}

The national values of Nigeria as indicated in the National Policy on Education [11] seeks to inculcate positive social values and attitude in a person in order to make him or her functional in the society. It is common knowledge that the Nigerian society is plagued by social vices like embezzlement, several national issues, insecurity of life and property, robbery, assassination, kidnapping and a host of other irresponsible attitudes which have done more harm to the lives and property of the citizenry than good. These social issues and problems have made Nigeria retrogressive as a nation, to the point that Nigerians have to look inwards and proffer solutions to salvage it if the country must develop as a nation. This is where the need for values education comes in to prepare the teeming youths to be good citizens in a complex world, where they will be forced to choose between competing values of good and evil. Values Education will go a long way to educate the youths on the importance of good behaviours, peace and security in the nation. Values education will help to solve social problems where the right values are fast being thrown away for the "get rich quick" syndrome. Values education helps to prepare the youths for the roles they will play in the society in the near future, in the various leadership positions they will occupy and of course as parents showing good examples to their children.

From the above, it is clear that values education places a premium on the development and inculcation of right values, attitudes, feelings, moral standards and the consciousness on the youths to choose right over wrong values. Youths with the right attitudes and values can only be assets to a nation thereby promoting national unity, peace and integration.

\section{The Concept of Social Reforms}

Social reforms are social changes or transformations whose sole purpose is geared towards positive changes in the society in all aspects of living. Such changes that are being sought vary from bringing down the crime rate in a given society, fighting vices like corruption, kidnapping, cultism, social unrest in various forms, threat to life and property, rape, vandalism of oil pipelines, fraud, inter- and intracommunity strife, etc. Successful social reforms will strengthen social institutions, increase employment opportunities, and of course increase the overall economic and financial standard of a nation.

Social reform is a kind of social movement that aims to make gradual change or change in certain aspects of society, rather than rapid or fundamental changes. A reform movement is distinguished from a more radical social movement such as revolutionary movements [3]. Social reforms seek to raise the quality of life for others and strengthen social institutions generally. One of the concerns of social reforms is to create awareness of some horrible living conditions in the society like threat to life and property, kidnapping, high rates of school dropout, etc. So, these social reformists work towards future change in these aspects that need to be looked into and operate within the framework of the law in a given society, with the ultimate aim of effecting a gradual change that will ultimately benefit the society as a whole.

Ololube, Uriah and Agbor [12] listed some characteristics of social reforms as follows:

a Social reform is continuous and permanent. It is a 
continuous process and is permanent in that it occurs all the time.

b Social reforms are not uniform. They can be fast or slow and the rate of change in societies, institutions and organisations varies, and

c Social reforms have relationships between sectors of the economy and society. Reforms that happen in one sector of a society often affects other sectors.

Finally, in developed and developing nations, frequent innovations and reforms take place because of the various changes in the cultural, economical, social and political dispositions of such countries [13]. It is believed that the knowledge of values education will significantly change the existing orientation, structure, functioning and efficiency of the general society at large in creating a lasting social reform in Nigeria.

\section{Values Education for Social Reform in Nigeria}

Education, being the process of teaching, learning and training of an individual brings about improved knowledge and the acquisition of skills. Education further liberates an individual from ignorance and helps one to choose the right values in the midst of good and bad values in a society. Education is the basis for scientific breakthroughs.

To curb social issues and problems in Nigeria and bring about lasting social reforms, there is a great need to teach values education to the youths at all levels of education to enable them function effectively in the society thereby reducing youth restiveness and insecurity in the society. If most youths in Nigeria have adequate knowledge of values education, it will go a long way in reducing social evils, youth restiveness and such insecurity situations that exist in the society. In order to promote a peaceful society, values education becomes imperative. Values education will enable an individual to live comfortably in a peaceful environment thereby making right choices at every point and contributing positively to the development of society. It is through the teaching of values education that youths will gain knowledge to decide on what is right or wrong, the enlightenment and orientation they will receive from values education will help them conduct their lives morally and make their lives more meaningful. They will have the insight to know what is right or wrong, be able to choose single-handedly good values from bad values, because the development of moral values within an individual is one of the major tasks of values education. The choice of good values makes our lives meaningful.

Agrawal and Agrawal [14] stated that education is a fundamental method of social progress and reform. The knowledge of social values creates a sound mind and moulds the character of an individual. Values education promotes a well-developed mind and character of an individual. It brings about peaceful and value-oriented society, as they reflect them in their attitudes and behaviours, thereby contributing positively to society through good citizenship.

For social reforms to take place, in order to salvage the various social issues and problems in Nigeria there is need for values education that will prepare individuals for the world of work ahead of them, exposing them to the choice of making good values - like hard work, honesty, discipline, cooperation, etc. to enable them function effectively in the society and things will be placed in the right perspectives. Roberts [15] conceptualised that to revitalise the potentials of the youths, and the eradication of social vices by the youths, which hinder economic developments, the government and every member of the society must play salient roles to address the social issues among the youths. Values education at the individual and societal levels will help to put things in the right perspectives. It is hoped that when individuals are engulfed in the right values, they will be transformed into embracing good values for a better society where individuals and even groups will shun violence, kidnapping, cultism, etc. and embrace togetherness, peaceful co-existence and transparency. Values education becomes imperative for social reforms because it creates in an individual the ability to make moral judgements based on sound reasoning, enables them to know what is important, worthwhile and worth striving for. Once learnt, values must be maintained, for those who deviate from the society's right values must be brought back in line. The knowledge of values education will go a long way in eradicating to an extent the youth restiveness, insecurity and other social issues and problems in the society. For social reforms to be effectively carried out, there is a great need for change in the knowledge acquisition, skills, interest and values indicators that will influence one's values in the making of choice. All these and more can be achieved through the knowledge of values education.

Values education will aid in facilitating social reforms as values reflect an individual's sense of right and wrong, what ought to be done or not to be done, gives direction to our behaviours. They express moral imperatives and help to define the ideal principle.

\subsection{Benefits of Values Education as a Panacea for Social Reforms}

Some of the benefits of values education as a panacea for social reforms are as follows:

(1) Values education provides a general guideline for best conduct and stability of social order.

(2) The knowledge of values education helps an individual to function effectively in a society, thereby reduces youth restiveness and other social issues and problems in the society.

(3) Values education enlightens an individual and helps to promote a well-developed mind-set that will be able to decide on choosing good values.

(4) Values education provides general guidelines for a person's behaviour which are translated into more specific directives in terms of roles and norms.

(5) Values education, once learned, those values taught are internalised and transmitted from one generation to the 
next.

(6) Values education helps an individual to acknowledge the right values, define what is worthwhile and worth striving for and with these, one is able to contribute positively to society and shun negative behaviours and attitudes.

(7) Values education enlightens an individual to determine what is considered right and wrong, beautiful and ugly, good and bad.

(8) Values education creates in an individual the ability to make the right decision about their personal lives, and the way they react to public issues and finally,

(9) It enables a person to choose the right values at any given point and enables one to contribute to the development of the society positively.

\subsection{Some Social Issues and Problems That Seek Reform in the Nigerian Society}

The Nigerian society is plagued with several social issues and problems that seek reform. These problems stand in the way of national development and peaceful co-existence among the citizenry. It is pertinent that these social issues that seek reform are known to enable decision-makers appreciate their effects on the nation, and seek solutions to curb them reasonably. Nigeria is in a crisis situation presently because majority of her population live in abject poverty. The inability of the youths to be engaged in worthwhile ventures have made them victims to various forms of social vices in a bid to survive with their families at any cost.

Ajufo [16] noted that lack of employment opportunities among the population of youths has been identified as a major factor responsible for youth restiveness and other social vices like armed robbery, prostitution, thuggery and destitution. Nwaosa, Ojohwoh and Jegbefun [17] also listed some consequences of poverty and unemployment amongst others as:

(1) Social unrest

(2) High rate of school drop out

(3) Threat to life and property, and

(4) Increase in crimes such as armed robbery, cultism, kidnapping, rape, bombing, ritual murder, drug trafficking, thuggery, oil bunkering, vandalism of oil pipelines, fraud and inter- and intra-community strife, corruption, examination malpractices, etc.

These are some of the social issues that seek reform in Nigeria. It is a truism that if majority of the people in a society lack education and the basic needs of life, there would be crises in such a nation. Social problems surface when people are denied their basic social rights and this makes it inevitable for the need for social reforms. Ediagbonya [18] noted that education remains a pivot upon which the wheels of society revolve. The knowledge of values education comes to play here as the key instrument to curb social unrest. The significance of values education cannot be overestimated because values form a basis for social interaction in every society. The knowledge of these values helps an individual to make the right choices at any given time and relate with others, thereby contributing to the development of a nation. The knowledge of values education will go a long way to create reform and reduce youth restiveness and insecurity in our society.

\section{Conclusion}

The paper examined values education as a panacea for social reforms in Nigeria. Values represent the final goals of a person's intentions, the person's choices are a reflection of his or her values. Given this focus, man as an individual will face many alternatives from which he has to make a choice. This, to an extent, depends strongly on what he considers priority. This priority is dependent on his attitude to life and what he values. A knowledge of values education will help the youths at any given time to weigh priorities among desirable values, and make right decisions, thereby changing their entire orientation. The introduction of values education into the curriculum at all levels will go a long way in curbing youth restiveness and other forms of social vices and remains a panacea for social reforms in Nigeria.

\section{Recommendations}

Based on the paper, the following recommendations were put forward:

1. Make values education compulsory at all levels of education.

2. The government should make values education functional by investing in adequate funding at every level of education.

3. The Ministry of Education at all levels should supervise schools and ensure it is functional.

4. Parents/Guardians and teachers should make it a priority to ensure moral and ethical values are being upheld.

5. Sensitise the public on the usefulness of values education to the development of society.

6. Awards should be made ready for youths that excel in maintaining right values at all levels of education.

7. Organise regular work-shops for teachers at all levels with skills and strategies to equip them in the teaching of values education.

\section{References}

[1] Ololube, N. P. (2011). Education and society: an interactive approach, Owerri: Spring Field Publishers.

[2] Mondal, P. N. (2018). Value education: definition and the concept of value education.

www.yourarticlelibrary.com/essay/value-education-definitionand-the-concept-of-value-education-with-example/30222/. Retrieved 20/11/2018.

[3] Wikipedia (2018). Values. https://en.m.wikipedia.org>wiki>value. Retrieved 20/11/2018. 
[4] Dorgu, T. E. \& Olu-Obafemi, E. C. (2017). 'Corruption at the basic education level: The role of religious and moral instruction in the realisation of good values' In Augustus, A. A., Buseri, J. C., Asuka, T. T., Egumu, A. C., Agih, A. A. \& Paulley, F. G. (Eds). (2017). Education for the reduction of corruption in Nigeria. Port-Harcourt, Nigeria. University of Port-Harcourt Press.

[5] Bodunrin, P. O. (2009). Unpublished post graduate seminar paper. Faculty of Education, Lagos State University.

[6] Bergmark, U. \& Alerby, E. (2008). Developing an ethical school through appreciating practice: Students' lived experience of ethical situations in school. Journal of Ethics and Education, 3(4), 41-55.

[7] Dike, V. E. (2007). Values education and national development. www.gamji.com/article400/NEWS4674.html. Retrieved 18/11/18.

[8] DeNobile, J. \& Hogan, E. (2014). Values education: what, how, why and what next? Curriculum and Leadership Journal, 12(1), 1-11.

[9] Robb, B. (2008). Values education - what it is? centre for alleviating social problems through values education. (CAVE). http://www.valueseducation.co.uk. Retrieved 20/11/18.

[10] Cox, E. (2007). Explicit and implicit moral education. Journal of Moral Education, 5(17), 92-97.

[11] Federal Republic of Nigeria (2013). National Policy on Education. Lagos: NERDC.
[12] Ololube, N. P., Uriah, O. A. \& Agbor, C. N. (2013). The nature of social change and its implications for educational management and planning. International Journal of Educational Foundations and Management. 1(1), 49-58. http://www.ijefm.com. Retrieved 20/11/18.

[13] Saba, M. D. (2009). Educational reforms in Nigeria: management focus. Korin Journal of Teacher Education, 5(1), 33-40.

[14] Agrawal, S. P. \& Agrawal, J. C. (1991). Educational and social uplift in backward classes: at what cost and how. New Delhi: Concept Publishing Company.

[15] Roberts, B. (2007). Youth and poverty: reduction strategy processed in sub-Saharan Africa. African Insight, 37(3), 432453.

[16] Ajufo, B. I. (2013). Challenge of youth unemployment in Nigeria: effective career guidance as a panacea: African Research Review. An International Multi-Disciplinary Journal. Ethiopia, 7(1), 307-321.

[17] Nwaosa, I. P., Ojohwoh, R. \& Jegbefun, F. M. (2013). Curbing youth restiveness in Nigeria through entrepreneurship opportunities in business education programme. A paper presented at the annual conference of the Institute of Education, Delta State University, Abraka, 11-17 June.

[18] Ediagbonya, K. (2013). The role of entrepreneurship education in ensuring economic empowerment and development. Journal of Business Administration and Education, 4(1), 35-46. 